\title{
Subjetividade e Estratégias de Resistência na Prisão
}

Subjectivity and resistance strategies in prison

Cristian Fabiano Guimarães, Stela

Nazareth Meneghel \& Carmen Silveira de Oliveira

Universidade do Vale do Rio dos Sinos

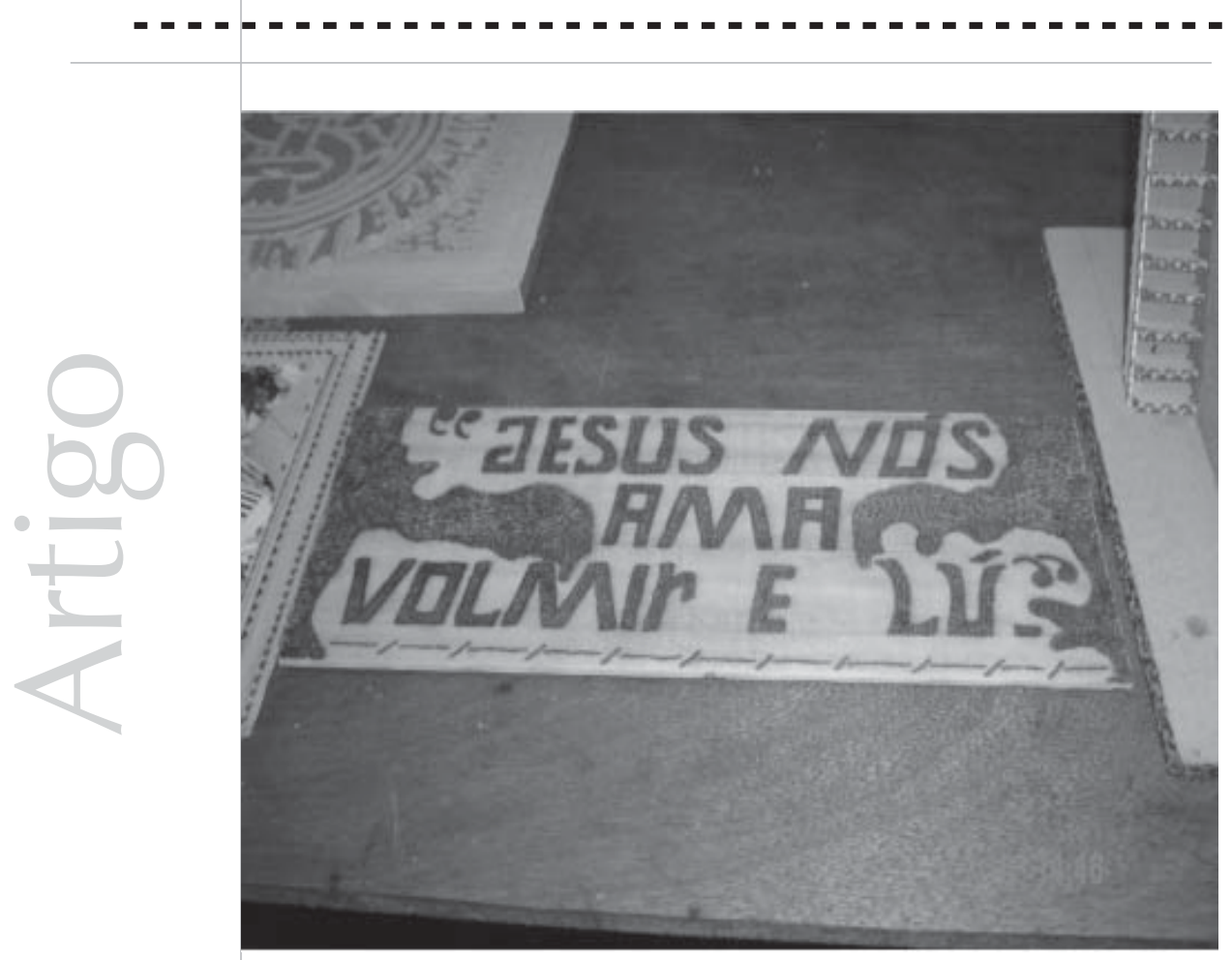




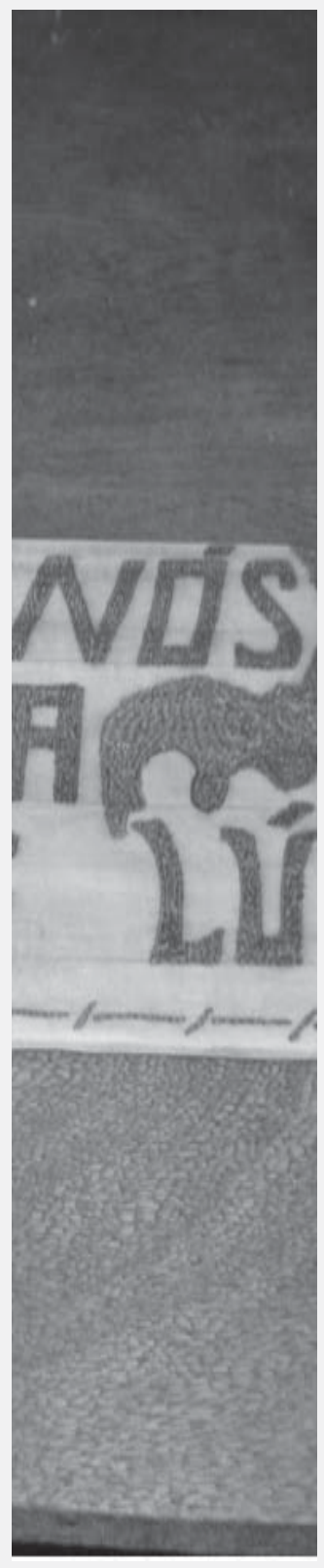

Resumo: Este estudo aborda a produção de subjetividade num presídio brasileiro de regime semi-aberto, com homens albergados. O objetivo da pesquisa foi compreender os modos de subjetivação e identificar as estratégias de resistência como táticas de enfrentamento às violências. Construiu-se um processo investigativo cartográfico, utilizando como ferramentas a observação participante, a fotografia, entrevistas semiestruturadas e a análise de documentos. Além disso, foi organizado um grupo-dispositivo, que buscou identificar e disparar resistências. Constatouse a existência de modos de subjetivação delinqüentes no presídio e o uso de resistências reativas, como a vitimização e o consumo abusivo de drogas. Entre as resistências ativas que os albergados encontram para sobreviver no presídio, estão: os códigos internos, as produções artísticas e a ruptura com o discurso de vítima. Este artigo valoriza a produção de subjetividades dos apenados e mostra existir resistência no cotidiano da prisão.

Palavras-chave: subjetividade, prisões, resistências, esquizoanálise.

Abstract: This study approaches the production of subjectivity in a penitentiary of half-open regime Brazilian prison system with a group of lodged men. The study main goal was to comprehend the ways of subjectivity and identify the resistance strategies as instruments to face violence. It was build a cartographic investigative process, using as tools the participant information, the photography, half structured interviews and the documents analysis. Besides that it was organized a directive group, in which it was aimed the identification of the active resistance. It was verified the existence of delinquent ways of subjectivity in the penitentiary, plus the use of reactive resistance, such as victimizing and abusive drug consumption. Among the active resistance that the lodged men found to survive in the prison are: the internal codes, the artistic productions and the rupture with the victim's speech. This article valorizes the subjectivity production of the sentenced men and shows the existence of resistance in the prison daily routine.

Key words: subjectivity, prison, resistance, esquizoanalysis.

As violências representam atualmente um grave problema de saúde pública, solicitando a atenção dos trabalhadores de saúde e, em especial, os de saúde mental, vistas suas implicações sobre a subjetividade dos sujeitos. A juventude tem sido um dos grupos mais atingidos pela violência, conforme mostram os dados epidemiológicos de homicídios no País e sua elevação nas últimas duas décadas (Waiselfisz, 2004).
A relação violência e saúde ainda deixa lacunas em relação à resolutividade dos trabalhadores de saúde, pouco capacitados para desenvolver ações propositivas de enfrentamento à violência. Na maioria das vezes, esses trabalhadores enfrentam situações de violência no cotidiano de trabalho ou nas suas relações, sendo eles também vítimas dela. Para entender esse fenômeno em sua manifestação coletiva e polissêmica, é urgente repensar o
"Talvez seja possível construir o futuro a partir de uma prisão"

T. Negri 
A prisão é uma tecnologia de punição que foi elaboradana modernidade, quando os mecanismos de poder evoluíram das sociedades de soberania para as sociedades disciplinares

Foucault modelo biomédico que sustenta as práticas sanitárias e pensar um conceito ampliado de saúde, resgatando sua complexidade e concretizando ações interdisciplinares. Além disso, o trabalho centrado no indivíduo deve ser complementado com experiências que superem a perspectiva individual apenas, utilizando a força dos grupos enquanto agentes multiplicadores de ações no enfrentamento da violência.

Nessa perspectiva, este artigo apresenta o resultado de uma pesquisa sobre processos de subjetivação e resistência de um grupo de apenados, procurando entender como se dá a captura da subjetividade na prisão. Esses homens podem ser vistos como parcela da população que se encontra em situação de inclusão diferencial, expostos às diversas situações de violência, reproduzindo-as.

As condições de saúde e sobrevivência dos apenados no interior dos estabelecimentos prisionais são as mais precárias, pois muitos desses homens estão doentes e não recebem atenção à saúde (Câmara dos Deputados, 2000). Essa constatação soma-se à indiferença e ao preconceito da sociedade em relação a esse grupo populacional. Diante da situação de precariedade em que sobrevivem, partimos da idéia de que eles constroem estratégias para chamar a atenção da sociedade para seus "fiapos de vida" (Pelbart, 2003, p.23) e para lutar contra o esquecimento ao qual estão entregues, funcionando essas estratégias como mecanismos para minorar o sofrimento e o estigma que sofrem.

A preocupação em viabilizar atenção à saúde para a população carcerária é um tema novo, entretanto, a saúde - e, principalmente, a Medicina e a Psicologia - estiveram ligadas à prisão desde sua origem, no século XVIII. Diante disso, exploramos, de forma breve, a construção histórica da relação saúde e prisão para, em seguida, contextualizar o momento atual.
Nosso ponto de partida é o entendimento de que a atenção à saúde na prisão surge como campo de conhecimento que valida o aprisionamento do indivíduo, participando da normatização do apenado e do funcionamento "ótimo" do sistema prisional.

A prisão é uma tecnologia de punição que foi elaborada na modernidade, quando os mecanismos de poder evoluíram das sociedades de soberania para as sociedades disciplinares (Foucault, 1987-2000). Essa transformação implicou a reestruturação do Estado e do aparelho jurídico para compor a organização social que começou a tomar forma nos séculos XVII e XVIII, quando o trabalho emergiu como valor central, assim como um conjunto de saberes encarregados de normalizar o indivíduo e auxiliar a governabilidade estatal. Junto a isso, toma forma uma medicina voltada para o social, com o movimento que Foucault (1979) denominou de medicina social, no qual o saber médico se transformou, nessa vertente, em disciplina do cuidado dos corpos, a fim de que contribuir para a manutenção da aptidão dos indivíduos para o trabalho.

No decorrer dos séculos XIX e XX, a participação da Medicina nas prisões esteve intimamente relacionada com o desenvolvimento das tipologias do criminoso, calcadas na idéia de desvio, sendo que essas noções permanecem nos interstícios dos discursos atuais (Rauter, 2002). Nessa época, passa-se a acreditar que o conhecimento da vida do criminoso e de suas características pessoais possibilita dar sentido ao crime, a partir de um saber médico-científico positivo. Disso surgem estudos, em Medicina legal, que objetivavam a tipologização do delinqüente, sustentando um modelo considerado "preventivo". Esses estudos tinham por objetivo identificar precocemente, a partir de um biótipo específico, indivíduos com propensão à delinqüência. Atualmente, correntes de pensamento comportamentalistas 
ainda buscam a relação entre o crime e personalidade patológica (Cidade, 1998; Minella, 1998; Lipp \& Serrat, 1983).

Esse quadro aponta a necessidade de investigações, principalmente em saúde mental coletiva, que superem modelos normativos e patologizantes, pois estes contribuem para o assujeitamento dos apenados e a manutenção desse status. Diante disso, optamos por deixar de lado o conceito de saúde como ausência de doença e a leitura normativa que ele implica; entendemos saúde enquanto movimento de superação do aprisionamento em forças reativas, estratégia de resistência que arranca da existência a vida onde ela está aprisionada. Por isso, nosso objetivo é identificar os modos de subjetivação dos apenados no presídio e resgatar as estratégias de resistência à vida na prisão enquanto dispositivo de promoção de saúde mental. Promoção de saúde é a transformação dos processos individuais de tomada de decisão em ações coletivas que favoreçam a saúde e a melhoria das condições de bem-estar, sendo a estratégia de promoção um movimento social, político e cultural (Buss, 2003).

Desenvolvemos este estudo em uma cidade de população predominantemente jovem, com serviços de saúde pouco operantes e escasso número de trabalhadores de saúde mental atendendo na rede de saúde. Nesse Município, as mortes por violência são grave problema de saúde pública, prevalecendo elevadas taxas de mortalidade por causas externas, com destaque às agressões e lesões autoprovocadas. Além disso, os transtornos mentais aparecem como uma das principais causas de morbidade no Município (IBGE/ AMS, 2000; MS, 2004).

Do ponto de vista econômico, destacam-se o setor de comércio e a indústria coureirocalçadista, esta última profundamente afetada pela crise nos anos noventa (Soethe et al., 2001), apresentando alguma melhora, atualmente, devido aos investimentos governamentais em exportação. O desemprego e a precarização do trabalho, aliados à insuficiência de políticas públicas, contribuíram para configurar um quadro de extrema desigualdade, condenando grandes contingentes populacionais à situação de pobreza. Apesar de o assalariamento nunca ter se colocado no Brasil como perspectiva real para toda a população, o problema do trabalho e o "sem lugar" produzido pela insuficiência de apoio em redes sociais se intensificam. Ao mesmo tempo em que surgem novas políticas públicas nos anos noventa, elas são ineficazes para o estabelecimento de redes sociais, na medida em que criar possibilidades de acesso não significa que os indivíduos realmente acessem essas redes de apoio.

Assim, desenvolvemos esta pesquisa buscando contribuir com os estudos em saúde mental e criminalidade que rompam com os modelos normativos fundamentados no patológico, no controle do excesso e na adequação às normas da prisão. O objetivo principal deste estudo foi compreender os processos de subjetivação de sujeitos albergados em um presídio e identificar as estratégias de resistência à vida na prisão como elementos possíveis de subsidiar as políticas de enfrentamento à violência.

\section{Processo investigativo}

Esta pesquisa foi realizada num presídio brasileiro de regime semi-aberto. A população presidiária é composta de cinqüenta homens, entre vinte e vinte e nove anos, de um total de cem sujeitos no momento do estudo, evidenciando uma população carcerária jovem (Alves \& Silveira, 2004). Esses albergados são, em sua maioria, moradores das cidades vizinhas ao Município onde está estabelecido o presídio em estudo, na região metropolitana de Porto Alegre-RS e do Vale do Rio dos Sinos. Alguns deles descendem de grupos de 
migrantes que chegaram à região em busca de melhores condições de vida. Mais da metade é de baixa renda e não completou o ensino fundamental. Anteriormente à prisão, desenvolviam atividades no comércio, no setor coureiro-calçadista ou na construção civil.

Esse presídio apresenta a particularidade de funcionar como um albergue, com capacidade para cento e vinte vagas, cuja especificidade é abrigar apenados em regime semi-aberto e aberto, muitos aguardando a finalização da pena. Eles possuem permissão judicial para sair do local mediante comprovação de trabalho, voltando apenas para dormir. É característica desse estabelecimento a alta circulação de presos para outras penitenciárias de regime fechado no Estado, sendo que a maioria dos homens que atualmente residem no estabelecimento já experimentaram o regime fechado.

Propomos, nesta pesquisa, um processo investigativo cartográfico. A cartografia é um processo de intervenção, quando da passagem do cartógrafo-pesquisador pelo território da pesquisa, quebrando a dicotomia sujeitoobjeto e instaurando uma relação onde os dois se constituem no mesmo processo, questionando os sentidos dos movimentos que se produzem no ato de pesquisar e explicitando a expressão das singularidades (Barros \& Passos, 2000).

A cartografia é um antimétodo (Rolnik, 1989) que procura revelar as forças que contribuem para a formação de territórios existenciais, ou seja, a constituição da vida dos sujeitos. Não existe protocolo normatizado para ela, cabendo ao cartógrafo construí-lo. A cartografia produz mundos, ou seja, redes de significações, por isso, o cartógrafo está interessado em atentar para o novo, para o que produz diferença num campo aparentemente homogêneo, quebrando as seqüências lineares de fatos e dando visibilidade às forças de resistência. Ela é considerada uma intervenção na medida em que, no encontro entre cartógrafo e sujeito, ambos se afetam e mudam. A proposta desse tipo de pesquisa-intervenção é descrever e compreender, com rigor, o que é vivenciado/ experenciado/inventado no decorrer do estudo, explicitando o caminho que se faz para colocar e responder ao problema estudado. Em relação ao cartógrafo, podemos dizer que sua prática diz respeito às estratégias de formação do desejo no campo social (Guattari, 1992; Rolnik, 1989), potencializando o desejo no seu caráter processual e (re)produtor da sociedade. Para Diógenes (1998), esse processo de investigação requer abertura do pesquisador para o novo, experiência do estudo, com disponibilidade para ver, escutar e deixar-se tocar pelos processos originados na investigação.

Utilizamos o diário de campo, onde registramos as observações das visitas ao local, as conversas e as percepções, bem como os apontamentos do referencial teórico para dialogar com os achados. No decorrer do estudo, sentimos a necessidade de agregar outras ferramentas auxiliares: entrevistas semiestruturadas com atores que trabalham com o tema (Promotor de Justiça jornais locais, psicóloga e assistentes sociais) e análise de documentos (relatórios e reportagens de jornais). Os informantes-chave - participantes da pesquisa, que se relacionam de alguma maneira com a questão carcerária - totalizaram um grupo de seis sujeitos. São eles: dois administradores penitenciários, um agente penitenciário, uma psicóloga, uma assistente social e um Promotor de Justiça.

Outras ferramentas da cartografia foram os elementos imagéticos obtidos por meio de fotografias, com o objetivo de registrar as marcas dos apenados no interior do estabelecimento prisional. Visualizamos, nessas marcas, indícios de estratégias de resistência desses apenados, e, por isso, a importância dada ao registro desses desenhos, mensagens, poesias ou grafitagens feitas por eles e deixadas na memória do estabelecimento. 
Realizamos um grupo-dispositivo (Barros, 1997; 1995; 1994), com treze apenados de diversas idades, que cumpriam pena devido a diferentes tipos de delitos, e que se dispuseram voluntariamente a participar. $\mathrm{O}$ objetivo do grupo foi problematizar, com eles, a vida na prisão, procurando identificar e compreender as estratégias de resistência que descobrem, inventam ou reproduzem. Esse tipo de grupo é capaz de desterritorializar e romper modos de subjetivações homogêneos e podem fazer emergir singularidades. São características do grupo-dispositivo a escuta supramoral e o desbloqueio de códigos de sentido único, conectando-se com as processualidades e produzindo modificações em territórios constituídos, com o deslocamento dos lugares naturalizados pelos sujeitos em busca da invenção de alternativas para a vida.

Esta pesquisa foi aprovada pelo Comitê de Ética da UNISINOS e todos os participantes assinaram o Termo de Consentimento Livre e Esclarecido - TCLE e o Termo de Cessão de Uso de Imagem livremente. O grupo-dispositivo foi filmado e posteriormente as falas foram compiladas para análise. A cartografia buscou problematizar os resultados produzidos ao longo da investigação através das ferramentas e da articulação com o referencial teórico.

\section{Cartografia dos modos de subjetivação e estratégias de resistência}

Os modos de subjetivação são os territórios existenciais subjetivos. Enquanto graus de intensidade ou efeito expressivo de forças, dizem respeito às diferentes formas de produção de subjetividades em uma formação social, ou seja, produzem modos singulares de curvatura sobre si de um certo tipo de força (Silva, 2004; Deleuze, 1988). Para Guattari \& Rolnik (1986), um modo de subjetivação se relaciona à busca de uma estabilidade na subjetividade em torno de um certo tipo de relação consigo. Conforme Deleuze \& Guattari (1966), o indivíduo consome os estados que passa e nasce desses estados, e, se entendermos subjetividade também como a expressão do desejo do indivíduo, percebemos, na necessidade de manter e fazer funcionar a prisão, a máquina que mobiliza o desejo dos apenados e fabrica o seu assujeitamento. Também na prisão, os modos de subjetivação são constituídos pelo caleidoscópio de forças, incluindo as relações de poder imanentes ao capitalismo, capazes de produzir subjetividades.

A subjetividade é produção social, e, nas sociedades capitalistas, o modo de produção de subjetividade dominante é chamado por Guattari (1986) de capitalístico, o qual fabrica a relação do homem com o mundo e consigo mesmo e projeta a realidade do mundo e a realidade psíquica sobre a vida enquanto sujeição. A máquina capitalística produz subjetividades que podem ser encontradas em qualquer nível de produção ou consumo, através da criação de indivíduos normalizados, submissos e reconhecidos numa mesma identidade.

Esse poder opera uma dupla opressão, que se reproduz tanto em nível dos oprimidos quanto dos opressores: primeiro conduz à repressão no campo econômico e social, e segundo, trabalha na produção de subjetividades enquanto base de formação da força coletiva de trabalho e de controle social coletivo. Os mecanismos que conduzem à dupla opressão constituem: a culpabilidade, a segregação e a infantilização, que operam na prisão a partir da pena (Guattari \& Rolnik, 1986).

A culpabilidade é o mecanismo que leva à interiorização de valores pré-estabelecidos e à conseqüente cobrança interna desses valores. A segregação e a infantilização produzem o isolamento social do preso e a incapacidade de falar em voz própria, respectivamente. A punição é aplicada pela máquina-prisão e mediada pelo Estado
A subjetividade é produção social, e, nas sociedades capitalistas, $\mathrm{O}$ modo de produção de subjetividade dominante é chamado por Guattari (1986) de capitalístico, o qual fabrica a relação do homem como mundo e consigo mesmo e projeta a realidade do mundo e a realidade psíquica sobre a vida enquanto sujeição. 
(Justiça), enquanto a pena é uma medida de ajustamento aos valores sociais que pretende extrair da culpa pelo crime uma "mais-valia" que conduz à adequação às normas. Como o indivíduo culpado não tem condições de aplicar-se uma penitência, cabe ao Estado reparar a sociedade e executar essa tarefa. $\mathrm{O}$ indivíduo é infantilizado na medida em que mantém uma relação de dependência do Estado, pois este se apropria da função de pensar e organizar a vida do preso.

Esse modelo, em parte, corresponde à sociedade disciplinar, pois o alvo da pena é a correção e a adequação do indivíduo. A partir do momento em que novas técnicas disciplinares foram desenvolvidas e em que uma outra tecnologia de poder passou a operar sobre a subjetividade, a função da prisão evoluiu da exclusão para a inclusão diferencial. A inclusão diferencial corresponde à tecnologia de poder da sociedade de controle; conforme Hardt (2000), a dinâmica capitalística é inclusiva, pois fabrica riqueza e miséria ao mesmo tempo. Isso indica que o capitalismo não opera por exclusão na sociedade de controle, mas a partir de uma estratégia de inclusão diferencial, onde cada indivíduo participa e sustenta, de alguma maneira, o sistema. Essa inclusão diferencial utiliza a prisão como exemplo, pois ela acena e efetiva, mediante a sociedade, a punição para os infratores que transgredirem as normas capitalísticas.

Nesse sentido, Wacquant (2001a; 2001b) sinaliza a função da prisão no contemporâneo, sustentando a tese de que ela possui importância fundamental na manutenção do neoliberalismo, na medida em que apresenta uma ameaça de punição e controle dos excessos e desvios, por adequar os indivíduos a um modelo de trabalho precário e desregulamentado. Essas "prisões da miséria" validam o modo de produção de subjetividade contemporâneo, produzem subjetividades punitivas e realimentam a necessidade da prisão, na medida em que identificam, na pobreza, indivíduos perigosos e potencialmente criminosos que necessitam do seu controle (Coimbra, 2001; Wacquant, 2001a; Wacquant, 2001b; Hardt, 2000).

Se as principais características do modo de produção de subjetividade capitalístico são a alienação do desejo e a interiorização de formas homogêneas de ser, pensar, agir e sentir, observa-se que essas são características marcantes no local de estudo, pois a manutenção do poder de punir depende, em certa medida, do estabelecimento de uma política de homogeneização da "massa carcerária". Nesse sentido, chamou atenção na pesquisa o fato de que os apenados participam no controle de si mesmos, capturados pelo modo de subjetivação próprio da máquina-prisão, que inibe resistências e os envolve no funcionamento do estabelecimento prisional, isso porque a prisão dispõe de um modo específico de produção de subjetividades que suscita a colagem do apenado no território delinqüente. É a partir da leitura desse maquinário que Foucault (2003; 1987-2000) identificou a prisão com uma fábrica de delinqüentes.

No território delinqüente produzido pela máquina prisão, emergem resistências ativas e reativas. A cartografia dessas estratégias demonstra, de um lado, os pontos onde a subjetividade é capturada pela máquina-prisão, e, de outro, as singularidades que lutam contra o sentido único fixado pelo modo de produção capitalístico, que insere a subjetividade dos apenados na categoria desviante-delinqüente.

O modo de produção capitalístico cria mecanismos que alimentam o status quo e conduzem à vigilância e à punição dos "desviantes" não inclusos no modo de produção, estimulando subjetividades vigilantes e punitivas. O sujeito é alvo de controle, e as resistências ativas - ou a potência criativa de novas formas de vida - são inibidas, 
aprisionando a vida em valores capitalísticos. Esse modo de produção formata o desejo e define um modelo ideal de vida, limitando as singularidades ao seu modo de produzir valor, através de procedimentos prescritos para fixar as identidades, mantê-las ou transformá-las em função de determinados fins, esvaziando a subjetividade de singularidade em processo para transformá-la em identidade (território fixo).

Nesse sentido, as resistências no sentido negativo, ou reativas (Rolnik, 2001), são as ações que conduzem à aderência do sujeito a um modo de produção de subjetividades marcado pelo individualismo e identidade fixa. São, portanto, estratégias em ressonância com o modo delinqüente que mantêm esse território em ação e reproduzem o assujeitamento dos apenados, pois ativam a vitimização desses homens.

Na pesquisa, observamos que os apenados se percebem e atuam como criminosos, barganhando muitas de suas necessidades às margens da lei. Esses homens utilizam a identidade criminosa para obterem as mais variadas vantagens no convívio social, fazendose valer do medo e intimidação que provocam em virtude de serem considerados perigosos. Afirmam sentirem-se potentes quando obtêm conquistas através de ameaças, utilizando o território delinqüente como alternativa de reconhecimento social por meio do uso do poder de intimidação.

No estudo que realizamos com as mulheres desses presos (Guimarães et al., 2006), elas relataram que os homens exercem mecanismos de controle e vigilância mesmo dentro da prisão. Elas são vigiadas e ameaçadas pelos amigos ou familiares do apenado, ocasião em que é possível observar a operacionalização do território delinqüente ao efetivar essas ações. As mulheres expressaram atitudes contraditórias em relação a esses comportamentos, pois, de um lado, usufruem a proteção e as regalias que isso acarreta na comunidade, e, de outro, sentem-se intimidadas e invadidas.

Utilizamos, como indícios para mapear os territórios, as marcas deixadas pelos apenados nas paredes do presídio. Nelas podemos identificar a fixação na identidade do indivíduo que cometeu um ato infracional, a partir do reconhecimento da infração ao código penal pela qual foi condenado. A assinatura abaixo das declarações de amor, dos desenhos ou das mensagens não carrega o nome, mas o código penal, como, por exemplo, a recorrência aos artigos 121 e 157 respectivamente, homicídio e roubo (figuras 1 e 2). Percebemos que os apenados são identificados e se reconhecem no crime pelo qual foram condenados, ao mesmo tempo em que estabelecem relações hierárquicas conforme o grau de periculosidade ou de valorização do crime cometido.

As estratégias de resistências reativas utilizadas por esses homens aparecem nos discursos que produzem. Eles nos contaram suas histórias, falaram de si mesmos e de suas experiências, entretanto, os enunciados estavam acompanhados de um pedido implícito de confirmação de suas falas. De um lado, o que nos comunicavam se aproximava do senso comum, e, por outro lado, transmitiam o que imaginavam que gostaríamos de ouvir sobre eles. O discurso da "pretensa inocência" e da vitimização no interior da prisão, por exemplo, mobiliza um modo queixoso nesses apenados e até mesmo de desresponsabilização por si mesmos e pelos atos cometidos. Assim, eles se disseram inocentes, que pagavam por um crime não cometido, ou seja, que o Estado e a Justiça estão numa relação de dívida para com eles. Entre as queixas, denunciaram a existência de duas justiças, uma para pobres e outra para ricos, e nos contaram que estar em melhores condições financeiras faz diferença dentro da prisão, pois o tratamento é diferenciado. Disseram não conhecer mais o mundo "lá fora" e expressaram sentir

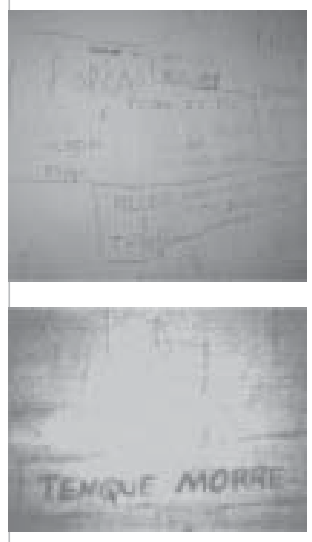

Figuras 1 e 2: Mensagens escritas nas paredes das celas 
dificuldades de comunicação devido ao tempo de prisão; reclamaram da sujeira do estabelecimento e dos duros castigos que sofrem quando são trancados no "cofre" (solitária) e ficam dias sem ver o sol ou tomar banho.

As condições físicas e sanitárias do local requereriam o fechamento imediato do estabelecimento, visto o risco para a saúde dos albergados e da equipe que trabalha no local, devido às condições insalubres e à falta de higiene, conforme os dados do comando regional de bombeiros da cidade e do Relatório de Inspeção da Vigilância Sanitária Municipal, ambos de 2003. Acrescentam-se os problemas de saúde freqüentemente encontrados nas prisões e a utilização de drogas lícitas e ilícitas. De acordo com pesquisa realizada no estabelecimento, 50\% dos albergados entrevistados se referiram ao uso de álcool, $43 \%$ deles, pelo menos uma vez, experimentou maconha, e 9\% utilizou cocaína (Alves \& Silveira, 2004). Entretanto, sabemos que a real situação do consumo de drogas nos presídios é ainda maior, pois geralmente o apenado omite fazer uso de substâncias psicoativas, já que esse dado concorre para aumentar a pena.

Contudo, eles contam que, à noite, depois da chamada, pulam o muro, vão a bailes ou para casa dormir com suas mulheres; dispõem de DVDs e celulares nas celas, compram bebidas alcoólicas e drogas, e expõem as fragilidades e os acordos tácitos que garantem alguma eficiência ao sistema prisional. Por vezes, praticam novos atos ilícitos, como foi o caso de dois deles, que cometeram um homicídio numa dessas saídas noturnas. Quando essas irregularidades se tornam aparentes, os agentes penitenciários incentivam os apenados a fugir, fato que inevitavelmente os faz retornar ao regime de prisão fechada, reforçando o território delinqüente.
Esses depoimentos confirmam a idéia de que as prisões abrigam atividades que são ininterruptamente desenvolvidas às margens da lei, para garantir o "bom funcionamento" do estabelecimento (Menandro, 1984). No local de estudo, não é diferente, e é nesse contexto que acreditamos ser importante discutir as drogas no sistema penitenciário, pelo seu caráter de manutenção do aparelho prisão, o que representa uma resistência reativa desses homens. A naturalização das drogas na prisão é uma alternativa criminosa de grande utilidade para a instituição, pois auxilia o controle prisional por funcionar como agente de contenção de rebeliões e fugas, uma prática (in)conscientemente validada pelos administradores e agentes penitenciários.

Os apenados contaram que a droga é "o combustível da prisão", e que, sem ela, a "prisão explode", confirmando que o consentimento de uso de substâncias psicoativas no interior dos estabelecimentos prisionais exerce função de contenção. Contudo, essa atividade os coloca em um circuito de criminalização, pois contribui para o seu assujeitamento e para o aumento da penalização.

Ainda em relação aos discursos de vítima, o grupo dispositivo permitiu refletir sobre a construção de outros sentidos para modificar a sua realidade no modo como exploram os objetos de seu universo de referências. Esse movimento foi disparado em meio a acusações mútuas, enquanto narravam um acontecimento recente na prisão, quando houve uma infração e eles foram pressionados a delatar um companheiro. A partir desse depoimento coletivo, ficou claro o mecanismo de captura da máquina-prisão, quando "a prisão faz o possível para colocar um preso contra o outro."

A máquina-prisão sustenta o território delinqüente a tal ponto que o indivíduo se assujeita. Exemplo disso são os depoimentos 
de que a prisão ensinou aos apenados que crimes pequenos não compensam, pois eles afirmam que "crime pequeno é burrice". Frente à precarização do mundo do trabalho, eles deixaram claro que não têm ilusões, sabem que os mais atingidos pela falta de oportunidades são os menos qualificados, os mais velhos e os estigmatizados, entre os quais se incluem: "se não existe trabalho pro cara que não é preso, imagina pro preso."

Em síntese, tanto a micropolítica que envolve o território delinqüente quanto a eclosão de resistências reativas revelam o caráter conservador da política do desejo na prisão, pois, conforme Deleuze (1988), "o poder investe os dominados, passa por eles e através deles, apóia-se neles, do mesmo modo que eles, em sua luta contra esse poder, se apóiam, por sua vez, nos pontos em que ele os afeta" (p. 37). No entanto, esse território marca também pontos de resistência ativa nesses homens, que inauguram uma outra possibilidade de geografia para o desejo.

Antes de apresentarmos as estratégias de resistência em seu caráter de produção de mudança de lugar, um aviso: a tentativa de separar a resistência ativa da reativa tem caráter didático para facilitar a compreensão do leitor, pois elas não ocorrem separadas. Ao contrário, o desejo, na sua condição paradoxal, dispara a resistência ativa que, em seguida, pode ser capturada e transformar-se em reativa, ou vice-versa. Portanto, adentramos no território da resistência ativa sabendo que, pelo seu caráter de movimento, podemos apenas vislumbrá-la ou inferi-la, sem pretender reduzilas a categorias fixas.

\section{As estratégias de resistência ativa}

Resistência, no sentido positivo, é a criação de um outro ponto de vista, de uma outra política da subjetividade, onde viver é potência de criação de novos mundos, a serem forjados através de estratégias concretas de ação. A resistência é afirmativa porque é vontade de outra coisa, bifurcação em relação às formas atuais de mundo e das subjetividades (Kastrup, 2004). O principal emergente da resistência ativa é a construção de um outro espaço que provoque uma mudança de lugar. Delinqüente, no sentido etimológico do termo, é o que desaloja, ou seja, o que busca uma mudança de lugar: um "cair fora" de onde se está determinado (Rassial, 1999). Assim, o objetivo dessa resistência é permitir outras vias de circulação nesse "não-lugar" ocupado pelos apenados.

Na prisão, a resistência ativa procura extrair uma potência de vida com forte poder inventivo para esses homens, pois, conforme Deleuze (1988), "haverá sempre uma relação consigo que resiste aos códigos e aos poderes; a relação consigo é, inclusive, a origem dos pontos de resistência" (p.111). Potência é definida como uma qualidade molecular ou micropolítica no agenciamento do desejo, que faz vibrar possíveis outros a partir de um uso intensivo da própria vida, que resiste à captura a um modo de produção de subjetividade homogêneo. A resistência ativa pode ser observada "quando um grupo de presidiários compõe e grava sua música, [pois] o que eles mostram e vendem não é só a música, nem só suas histórias de vida escabrosas, mas seu estilo, sua vida. Seu único capital sendo sua vida, no seu estado extremo de sobrevida e resistência, é disso que fizeram um vetor de existencialização, é essa vida que eles capitalizaram e que assim se valorizou e produziu valor" (Pelbart, 2003, p.22).

Consideramos marcas o conjunto de produções artísticas, os sinais e signos encontrados na prisão, grafitagens e decoração das celas, assim como as marcas corporais tatuagens e adornos. As marcas deixadas por esses homens no corpo, ou evidenciadas nos desenhos nas paredes, frases ou declarações de amor encontradas no presídio, constituem
... "o poder investe os dominados, passa por eles e através deles, apóia-se neles, do mesmo modo que eles, em sua luta contra esse poder, se apóiam, por suavez, nos pontos em que ele os afeta"

Deleuze 


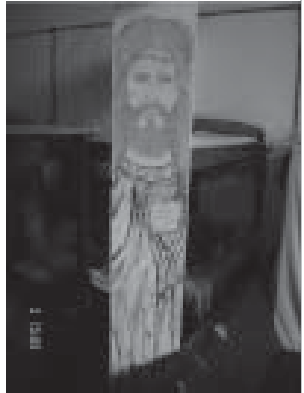

Figura 3:

Produção artística dos apenados

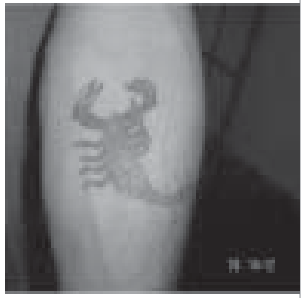

Figura 4: Tatuagem de um apenado figuras do desejo desses homens (figuras 3 e 4), expressam afetos e ensaios de construção de novos sentidos a partir da realidade em que estão imersos. As marcas denunciam maus-tratos, constroem couraças, expõem feridas, mas também remodelam espaços, contam histórias, mudam territórios e fazem novos mapas.

Ademais, consideramos a presença de resistência permeando os códigos internos dos apenados. Códigos internos são um conjunto de regras transmitidas e aceitas entre eles, que reproduzem um sistema de vigilância e punição em consonância com a máquinaprisão, pois a característica fundamental desses códigos é "o desenvolvimento de técnicas de poder orientadas para os indivíduos e destinadas a governá-los de maneira contínua e permanente" (Foucault, 1991, p.98). Os mecanismos de controle da máquina levam à necessidade de criar códigos internos como alternativa para sobreviver na prisão, e contribuem para modelar as relações dos apenados de acordo com os códigos.

Esses códigos constituem as regras da microssociedade prisional, formada por regulamentos que punem com rigor, mas que também definem condutas/atuações coletivas e políticas não-colaboracionistas, introduzindo uma certa ética entre eles. São exemplos de códigos: o respeito ao dia de visitas e às famílias dos presos; a punição aos crimes sexuais; a atitude de não compactuar com a polícia; a preservação da intimidade; a não delação. É consenso que o não cumprimento do código implica represálias, as quais, nas palavras dos apenados, "são piores que punição de policial."

Consideramos os códigos resistência ativa porque auxiliam a construir os relacionamentos de grupo e estimulam a cooperação, que, por sua vez, provocam conscientização e fortalecimento. Exemplo dessa estratégia é o consenso de que a limpeza do estabelecimento prisional não deve ser realizada pelos apenados, pois o Estado é o responsável pela limpeza das prisões. A partir desse consenso, os apenados se negam a limpar o estabelecimento. Não nos interessa questionar se essa atitude é correta ou não, o importante é constatar, nesse movimento coletivo, a denúncia do abandono a que estão submetidos, o protesto por melhores condições de vida e o esboço de uma organização grupal.

De modo geral, o objetivo dessas estratégias de resistência é o de desautorizar os mecanismos de controle estabelecidos pela prisão que são reproduzidos nas relações desses homens, mecanismos que incitam ao individualismo, que estabelecem normas punitivas, que disciplinam e assujeitam, ou seja, que produzem, nas subjetividades, um único modelo, além de reforçar o território delinqüente, configurando a postura de vítima e conduzindo à anestesia da potência criadora. E é justamente essa atitude de cerceamento de novas singularidades que impede os apenados de desenvolver projetos de vida que rompam o território produzido pela máquinaprisão após o cumprimento da pena.

Ao constatar que o único sentido que resta a tais sujeitos é a maldição de "viver privado de toda possibilidade de futuro" (Onfray, 2001, p.67), indagamos quais são as possibilidades da emergência de um sujeito autônomo no contexto prisional. Acreditamos que uma perspectiva seja a de investir na potência criadora desses homens, o que se contrapõe à anestesia da máquina-prisão, onde eles permanecem imóveis na eterna condenação de ficar ou partir da prisão com a prisão. A resistência, em seu caráter ativo de movimento vital, que, antes de mostrar um caminho de volta, pretende apontar novos caminhos de ida, constitui uma das linhas de fuga, uma das rupturas com a máquina-prisão. As produções artísticas são caminhos para atravessar os muros das prisões e atingir a sociedade, pois a arte é um dispositivo que problematiza o meio onde ela se produz. 
Rolnik (2001) mostra que a produção constitui estratégia de resistência e manancial privilegiado de potência criadora, pois os artistas dispõem de subjetividades permeáveis aos movimentos da vida, cuja obra é "a cartografia singular dos estados sensíveis que sua deambulação pelo mundo mobiliza" (Rolnik, 2001, p.3). Para Pelbart (2003), a força das estratégias de resistência dos apenados reside na possibilidade de invenção de novas comunidades potenciais nas prisões: a comunidade dos artesãos, que transformam seus "fiapos de vida" em arte; a comunidade que resiste a partir dos códigos internos pautados em valores como cooperação e compartilhamento de poder; a comunidade do rap, que, por meio da expressão musical, considera que as grades podem prender o corpo, mas não os pensamentos, e muitas outras comunidades ou grupos a serem inventados, que transgridam o circuito delinqüente e a perspectiva vigilante e punitiva da máquina-prisão (figura 5).

Cabe salientar que, à atividade artística, não compete apenas tirar o apenado da ociosidade ou funcionar como alternativa de renda. $\mathrm{O}$ artístico, enquanto estratégia de resistência ativa, tem caráter de produção de sentidos e oferece passagem aos estados sensíveis experimentados por esses homens. Dependendo do destino da criação, pode significar o desmonte do território delinqüente, inclusive pelo desassossego que provoca na imagem social do delinqüente produzida no outro que adquire/compra o trabalho.

Além disso, a arte pode contribuir para o exercício do esquecimento, no sentido nietzscheniano, auxiliando esses homens a abandonar a postura de ressentimento que experimentam com o desejo de vingança. A transformação do ressentimento em esquecimento passa pela necessidade do relato dos acontecimentos trágicos, das violências e das injustiças, e, para isso, é preciso um ouvinte que rompa a fixação com o passado e a identificação com a díade mortífera vítima/ algoz. O ouvinte ou a testemunha é "aquele que não vai embora, que consegue ouvir a narração insuportável do outro, não por culpabilidade ou por compaixão, mas porque essa retomada reflexiva do passado pode nos ajudar a não repeti-lo infinitamente e ousar esboçar uma outra história e a inventar o presente" (Gagnebin, 2004, p. 93). Para romper o ressentimento, é preciso mobilizar a produção desejante dos apenados a fim de que se possa operar no presente, libertando os sentimentos aprisionados no passado. Esquecimento significa fazer um outro uso do passado enquanto atitude política, é a operação de se apropriar do passado, não para imobilizar-se na inércia, mas para construir o presente prosseguindo na luta (Rauter, 2002).

Ao descobrir ou inventar tais estratégias de resistência, os apenados podem fazer frente à violência, construindo espaços e modos inovadores de lidar com a criminalidade. Podem vir a ser agentes de transformação, pois dispõem de ferramentas aprendidas na vivência na prisão e conhecem as artimanhas do crime e suas redes de disseminação (figura 6).

\section{Considerações finais}

Pretendemos, com este estudo, garimpar os movimentos do desejo onde eles parecem inviáveis. Assim, percebemos que a engrenagem da máquina-prisão constrói e sedimenta um modo de subjetivação delinqüente, propiciando a inclusão diferencial do preso. Isso pode ser observado nas palavras de Wacqüant (2001a; 2001b), pois as prisões contemporâneas são as grades que prendem a produção da miséria do modelo neoliberal, onde os apenados participam ativamente de um circuito social que homogeneiza as subjetividades.

Quando o apenado se identifica com o modo delinqüente, o seu desejo é capturado,

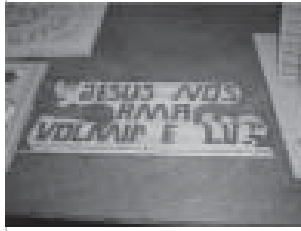

Figura 5:

Produção artística exposta no grupodispositivo.

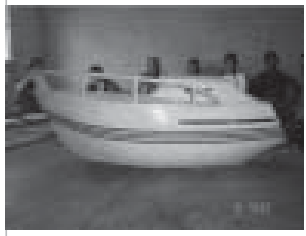

Figura 6: Barco construído por apenado e grupodispositivo 
tornando-o vulnerável. Despotencializado, ele é presa fácil dos artifícios da máquina-prisão, na constante tentativa de criar e sustentar sua demanda. Por outro lado, o apenado não é apenas passivo quanto à produção de subjetividade, pois, como vimos, existem pontos onde a singularidade escapa e possibilita a construção de outros sentidos possíveis.

As estratégias de resistência reativa utilizadas por eles são, sobretudo, contrapoderes que alimentam a máquina prisão. Por isso, não há como desmontar essa política de captura do desejo e a lógica opressora do sistema prisional se não interviermos na produção de subjetividades. A resistência ativa é um dispositivo de luta e desmonte do território delinqüente, pois carrega forte potencial de invenção, o que contribui com uma outra política do desejo na construção da subjetividade desses homens.

Em termos de políticas públicas para a população carcerária, destacamos que o trabalho da equipe técnica não deve se restringir aos pareceres ou às abordagens terapêuticas individuais. Assim, apostamos nos grupos dispositivos como espaços privilegiados de intervenção, tendo como objetivo a promoção da saúde mental desses homens.

Com relação ao Sistema Único de Saúde (SUS), há a necessidade de organizar a atenção à população apenada, de acordo com a Política Nacional de Saúde nos Sistemas Penitenciários (Ministério da Saúde e Ministério de Estado da Justiça, 2003), que tem como objetivo prestar atendimento à saúde nos presídios, dentro dos padrões de qualidade e diretrizes do SUS. No entanto, precisamos envidar esforços para que essa política se torne efetiva, pois o próprio sistema penitenciário não busca parcerias com os serviços da comunidade, os quais, por sua vez, consideram os presídios meros locais de "despejo."

Em suma, a prisão reproduz a sociedade em espaço fechado e constitui local privilegiado para compreender a dinâmica da própria sociedade bem como as estratégias de resistência que suscita (sejam elas ativas ou reativas). Nesse sentido, Deleuze (1988) comenta que, mesmo sem a prisão (a prisão enquanto materialidade), ela sobreviverá ao longo do tempo, numa clara alusão às redes de poder que fazem funcionar um modo de produção de subjetividades consoantes à máquina-prisão.

Cristian Fabiano Guimarães, psicólogo, Mestre em Saúde coletiva pela UNISINOS

Stela Nazareth Meneghel, médica, Doutora em Medicina pela UFRGS, professora do Mestrado em Saúde coletiva, UNISINOS.

Pós-doutora em Psicologia Social na UAB- Espanha.

Carmen Silveira de Oliveira, psicóloga, Doutora em Psicologia social pela PUC-SP, professora da UNISINOS.

Rua Tomás Flores, 197 - Apto 501 - Bairro Bom Fim. Porto Alegre-RS. CEP 90035-201

E-mail:cfguima@uol.com.br 
ALVES, C.; SILVEIRA, S. D. Relatório, 2004 (mimeo).

BARROS, R.B. Grupo e Produção. In: Saúde e Loucura: Grupos e Coletivos, no 4. São Paulo: Hucitec, 1994.

Clínica Grupal. In: Revista do Departamento de Psicologia UFF, Niterói-RJ, 7 (1), pp.5-11, 1995.

Dispositivos em Ação: o Grupo. In: LANCETTI, A. (dir). Saúde e Loucura: Subjetividade, no. 6, São Paulo: Hucitec,1997

BARROS, R.B. \& PASSOS, E. A Construção do Plano da Clínica e o Conceito de Transdisciplinaridade. In: Psicologia: Teoria e Pesquisa Brasilia, 6(1), pp.71-9, jan.-abr. 2000.

BUSS, P.M. Uma Introdução ao Conceito de Promoção de Saúde In: Czeresnia \& Machado Freitas (org). Promoção da Saúde: Conceitos, Reflexões, Tendências. Rio de Janeiro: Fiocruz, 2003.

CÂMARA DOS DEPUTADOS. II Caravana Nacional de Direitos Humanos. Relatório: uma Amostra da Realidade Prisional Brasileira. Brasília: Câmara dos Deputados, Coordenação de Publicações, 2000.

CIDADE, D.P. A Violência Humana e os Reclusos: uma Pesquisa na Esfera Psicológica. In: Aletheia, (7), pp.15-131, jan-jun.1998.

COIMBRA CMB (2001). Práticas Psi e Tortura no Brasil. Grupo Tortura Nunca Mais. Internet: http://www.torturanuncamais-rj.org.br. Acesso em 30 de Maio de 2004.

DELEUZE, G. Foucault. São Paulo: Brasiliense, 1998.

DELEUZE, G.; GUATTARI, F. O Anti-édipo: Capitalismo e Esquizofrenia. Lisboa: Assírio \& Alvim, 1966.

DIÓGENES, G.A Névoa Branca e o Monstro da Noite. In Cartografias da Cultura e da Violência: Gangues, Galeras e o Movimento Hip Hop. São Paulo: Anna Blume, 1998

FOUCAULT, M. O Nascimento da Medicina Social. In: Microfísica do Poder. 15a ed. Rio de Janeiro: Graal, 1979.

Vigiar e Punir. 23a ed. Petrópolis, RJ: Vozes, 2000.

Paidós, 1991

Tecnologías del Yo y otros Textos Afines. Barcelona:

Estratégia, Poder-saber. In: Coleção Ditos e Escritos IV. Rio de Janeiro: Forense Universitária, 2003.

GAGNEBIM, J.M. Memória, História, Testemunho. In: Bresciani, S. (org.) Memória e (Res)sentimento - Indagações sobre a Questão Sensível. Campinas: UNICAMP, 2004.

GUATTARI, F. Caosmose: um Novo Paradigma Estético. $2^{\text {a }}$ reimpressão. São Paulo:Ed. 34, 1992-1998.

GUATTARI, F.; ROLNIK, S. Micropolítica: Cartografias do Desejo. 5a ed. Petrópolis: Vozes, 1986-1999.

GUIMARÃES, C.F. et al. Homens Apenados e Mulheres Presas: Estudo sobre Mulheres de Presos. In: Psicologia e Sociedade, Porto AlegreRS, v. 18, 2006.

HARDT, M. A Sociedade Mundial de Controle. In: Alliez, E. (org). Gilles Deleuze: uma Vida Filosófica. São Paulo:Ed.34, 2000.

IBGE/AMS. Estatísticas da Saúde: Assistência Médico-sanitária Rio de Janeiro: IBGE, 2000.
KASTRUP, V. Competência Ética e Estratégias de Resistências. In: Guareschi, N. (org). Estratégias de Invenção do Presente: a Psicologia Social no Contemporâneo. Porto Alegre: EDIPUCRS, 2004.

LIPP, M.N. \& SERRAT, S.M. Atos Violentos contra Pessoas: Estudo de Fatores Causais. In: Estudos de Psicologia, PUCCAMP, Campinas, 1(1), 1983

MENANDRO, P.R.M. A Questão Carcerária: um Problema Técnico? In: Arq. Bras. Psic., Rio de Janeiro, 36(3), pp. 62-89, jul.-set.1984.

MINELLA, D.M.L. O Trabalho do Psicólogo junto às Penas Alternativas. In: Aletheia (7), pp. 51-4, jan.-jun.1998.

MINISTÉRIO DA SAÚDE. Sistema de Informações Ambulatoriais do Sistema Único de Saúde SAI/SUS. http://www.datasus.gov.br, acesso em agosto de 2004

MINISTÉRIO DA SAÚDE E MINISTÉRIO DE ESTADO DAJUSTIÇA CONSELHO NACIONAL DE POLITICA CRIMINAL E PENITENCIÁRIA. Plano Nacional de Saúde nos Sistemas Penitenciários: Portaria Interministerial no 1.777, de 09/09/2003. Internet, http://www.mj.gov.br/cnpcp/resolucoes/res2003n7.htm, acesso em fevereiro de 2004.

ONFRAY, M. A Política do Rebelde: Tratado de Resistência e Insubmissão. Rio de Janeiro: Rocco, 2001.

PELBART, P.P. Vida Capital: Ensaios de Biopolítica. São Paulo: lluminuras, 2003.

RASSIAL, J.J. O Adolescente e o Psicanalista. Rio de Janeiro: Companhia de Freud, 1999.

RAUTER, C. Clínica do Esquecimento: Estudo de um Caso. In: Raute et al. (org). Clínica e Política: Subjetividade e Violação dos Direitos Humanos. Rio de Janeiro: Instituto Franco Basaglia/Editora TeCorá, 2002. Revan, 2003

Criminologia e Subjetividade no Brasil. Rio de Janeiro:

ROLNIK, S. Cartografia Sentimental: Transformações Contemporâneas do Desejo. São Paulo: Estação Liberdade, 1989.

. Despachos no Museu: Sabe-se lá o que Vai Acontecer In: São Paulo Perspectiva, 15(3), São Paulo: jul.-set., 2001.

SILVA, R.N. A Dobra Deleuziana: o Mundo como Potência de Invenção. In: Engelman \& Fonseca (org). Corpo, Arte e Clínica. Porto Alegre: Ed. UFRGS, 2004.

SOETHE, J.R.E. et al. Vale dos Sinos: Resgate Histórico e Visão Popula do Desenvolvimento. Cadernos CEDOPE, Série Movimentos Sociais e Cultura, 12, São Leopoldo, Universidade do Vale do Rio dos Sinos, 2001.

WACQUANT, L. As Prisões da Miséria. Rio de Janeiro: Jorge Zahar, $2001 \mathrm{a}$

Punir os Pobres: a Nova Gestão da Miséria nos Estados Unidos. Rio de Janeiro: Instituto Carioca de Criminologia: F. Bastos, 2001b

WAISELFISZ, J.J. Mapa da Violência IV: os Jovens do Brasil. Brasília: Unesco, Instituto Airton Senna, Secretaria Especial dos Direitos Humanos, 2004.

\section{Referências}

